\title{
Making a 'Resilient Santiago': Private Sector and Urban Governance in Chile*
}

\author{
KATARÍNA SVITKOVÁ** \\ Institute of Political Science, Faculty of Social Sciences, \\ Charles University, Prague
}

\begin{abstract}
Resilience has become a policy and practical framework for addressing a range of threats from natural disasters and extreme weather events to political conflicts and terrorism. Focusing on the context of cities, this paper offers a conceptualisation of urban resilience, critically interrogating its use for urban governance and the political implications it has for individual agency. The paper also seeks to contribute to the existing critical literature on urban resilience. The second part of the paper focuses on the Rockefeller Foundation's 100 Resilient Cities programme as implemented in the Metropolitan Region of Santiago, Chile. Empirical data obtained through fieldwork and interviews with representatives of the public sector and civil society suggest that while creating an illusion of inclusiveness and empowerment, the 'resilience approach' has largely ignored the structural conditions of extreme social and spatial inequality in Santiago. Local political realities and private sector interests play an important part in this equation. The case study points to a general tendency to treat city resilience as a technical question, thereby downplaying its deeply political nature. It highlights the disconnection between the topography of risk on the one side and technological interventions on the other.
\end{abstract}

Keywords: cities, resilience, security, governance, Rockefeller, technology, Santiago

Sociologický časopis/Czech Sociological Review, 2018, Vol. 54, No. 6: 933-960

https://doi.org/10.13060/00380288.2018.54.6.436

\section{Introduction}

From academia to policy advocacy and corporate consultancy, the alarms are on: we live in an age of risk. It also happens to be an urban age, with the majority of the world's population now living in cities, and urban-related issues attracting a great deal of attention [see Jacobs 2005; Gleeson 2015]. Urban disasters may be

\footnotetext{
* Acknowledgements: This work was supported by project SVV 260461 / 2017 Zájmy, moc a instituce v politickém rozhodování.

** Direct all correspondence to: Katarína Svitková: Department of Security Studies, Institute of Political Science, Faculty of Social Sciences, Charles University in Prague, e-mail: katarina.svitkova1@gmail.com.
}

C Sociologický ústav AV ČR, v.v.i., Praha 2018 
triggered by different catalysts - extreme weather events, industrial and infrastructural failures, mass traffic accidents, and terrorism. Throughout the 2000s, a range of resilience-labelled measures, practices, and discourses proliferated in cities across the world.

The purpose of this paper is twofold. First, it seeks to examine the dominant conception of urban resilience as a universal, apolitical tool to secure cities and their populations. It does this by means of a critical conceptualisation along the lines of governmentality. The second objective of the paper is to contribute to the existing critical literature on resilience in general and urban resilience in particular through a case study of Santiago, Chile.

One of the principal arguments is that resilience is predominantly used as a technocratic tool, both in discursive and practical terms, which disregards its political context. It informs techniques such as quantifying, measuring, and indexing, which operationalise its regulatory and managerial logic [Rogers 2013]. Politically, however, resilience is 'useful to explain the endurance of [the existing] institutions and regimes [which] maintain [their] essential elements while building new approaches to social resilience' [Bourbeau 2017: 31]. Despite the discursive implications of the novelty of resilience, this process takes place along the 'political and cultural narratives of the neoliberal era' ${ }^{1}$ [ibid.: 32], as will be made apparent in this case study.

In this vein, the paper traces the use of 'resilience' as employed by a major privately funded non-profit organisation called 100 Resilient Cities, which is funded by the Rockefeller Foundation. In order to explore the role and the effects of private actors on 'resilience' policies in a context of pronounced socioeconomic inequality, it discusses the case of Santiago Metropolitan Region as a member of 100 Resilient Cities. The city of Santiago markets itself as one of the economic, investment, and cultural hubs of Latin America, while it is also profoundly influenced by deep structural socioeconomic inequality. Additionally, the Regional Government's keen interest in being put on the global urban resilience map has had some political motives. In terms of private sector involvement, the analysis suggests that private interests tend to favour resilience as a technocratic policy that can be planned, managed, and evaluated using a top-down and project-management approach. This leads to an extremely reductionist picture of what is a highly complex social and spatial reality. In the meantime, practices and discourses of

\footnotetext{
${ }^{1}$ Neoliberalism is a broad term, economic theory, and a time-period connected to economic liberalism, which emphasises the idea of free trade and argues for a roll-back of the state in the economy and society, while emphasising the role of the private sector in these arenas. It has been widely addressed and criticised in the social sciences regarding the structural adjustment reforms in the 1980s and especially their effects on developing countries and poor communities, which are still visible in the present day. For an overview of different streams and views of neoliberalism, see The Routledge Handbook of Neoliberalism edited by Springer, Birch and MacLeavy [2016]. For a critique of neoliberalism from an urban development perspective, see The Urban Condition by Gleason [2015].
} 
urban resilience have laid bare the interconnectedness between public and private actors in policy-making that directly influences millions of urban dwellers.

The paper critically interrogates the neoliberal public-private networks that have sprung up in Santiago, connecting global companies to metropolitan and local governments. The myriad of actors that constitute this network includes public administrations, tech companies, think-tanks, research centres, universities, NGOs, and transnational donors, and, crucially, their hybrid platforms and clusters. Thus, a wide range of public and private actors shape, produce, and design the standards of what urban resilience means. In this context, it is imperative to ask what types of governance practices are encouraged by resilience, and what types of actors have benefited from its momentum.

\section{When resilience became urban: the concept and the literature}

The term resilience is rooted in the Latin word resilientia, meaning an 'act of avoiding' or an 'action of rebounding' [Rogers 2017: 14]. The term appeared in the Glossographia dictionary by Thomas Blunt published back in 1656 and was used by Jan Amos Comenius in reference to school systems in the sense of the capacity to 'rebound' [Alexander 2013: 2709]. In the 19th century, it became widely used in mechanics, and the 20th century saw it proliferate in the areas of psychology and ecology [Hooling 1973], before it found its way into the other social sciences, particularly sociology and human geography [Alexander 2013: 2710-2712]. This is where the interconnection between the resilience of populations and that of their environment began to be studied.

The perception of cities and urban societies as being under a constant threat of adversity has led to a search for a universal solution in policy and practice. As risks and threats are incredibly varied in their nature and scope, the solution had to be all-encompassing, flexible, and tied to the referent object (the threatened value) itself. The concept of 'resilience' began to be used and understood as the capacity of a system to constantly evolve and adapt to disturbance while maintaining its basic function and structure [Walker and Salt 2006]. Different types of resilience have been distinguished, such as specified resilience vis-à-vis known risks and general resilience, which refers to unknown risks, with the latter requiring a more proactive stance [Scholz et al. 2012]. Elsewhere, resilience is seen as either a short-term coping capacity or the long-term adaptation of individuals and systems under stress [UN-HABITAT 2007: 168].

A number of transnational actors, both public and private, have incorporated resilience into their agendas and programmes, treating it as a universal strategy, a plan for action, a tool, or a desired objective. Focusing particularly on cities and urban development, the United Nations Human Settlements Programme (also known as UN-Habitat) highlighted the term in its Global Report on Human Settlements in 2007, using resilience as a key principle of urban development, prosperity, and security, and juxtaposing urban resilience and urban vulnerability [UN-Hab- 
itat 2007]. The United Nations Office for Disaster Risk Reduction has also made wide use of the resilience concept, particularly in its Sendai Framework for Action for 2015-2030. The 27-page text refers to resilience 39 times, turning it into the key concept in the discourse of global risk reduction. It also emphasises the role of the private sector in addressing the resilience of the environment and populations [UNISDR 2015]. The World Bank has advocated universal access to city-tailored financial instruments to ensure the resilience of the urban poor [Hallegatte et al. 2016]. For its part, the Organization of Economic Cooperation and Development has founded its own Resilient Cities programme [OECD undated].

The broad applicability of the 'urban resilience' concept has led practitioners, scientists, research centres, governments, and the private sector to take it up on their own terms. Resilience, in the sense of adaptation and perseverance in face of adversity, has become a trendy term for those who propose broadly-based solutions to specific problems within their own agendas. In the context of the vulnerability of cities to different types of threats and an omnipresent sense of 'uncertainty' and 'unpredictability', resilience aims for reassurance. It has become the dominant discursive and policy framework to 'help cities adapt' to any possible contingency. The resilience label is widely used in an effort to secure funding for specific projects, to reassert authority and legitimacy for employing particular security measures, and to be able to allocate resources in a certain way. In this context, I aim to examine the concept of resilience as a universal tool used by governments to secure cities and their inhabitants.

At the same time, resilience as a concept has become subject to different interpretations for different purposes and, thus, widely contested. Simply put, 'resilience means different things to different people' [Walker and Salt 2006: 37]. It has been applied in highly diverse and context-specific ways, and questions have been asked about how variables for 'measuring' resilience are chosen [Prior and Hagmann 2013], that is, about whether resilience can be 'measured' to begin with. Some have criticised the concept of resilience for being too vague to be analytically useful [Friend and Moench 2013; Gleeson 2015: 97]. For others, resilience is simply an excuse to give up on sustainability [Gleeson 2015]. In order to look beyond the dominant problem-solving understanding of resilience, I also approach the term as a discursive and practical tool that is being increasingly used by the private sector to pursue its corporate objectives.

\section{Resilience and the private sector}

Cities and city administrations constitute profitable markets for private sector, which is both prestige- and benefit-driven. Specifically, participating in urban resilience networks and consortia grants companies direct access to policy-making across all levels and sectors. At the same time, it opens the doors to public investment in 'urban resilience' technologies, ranging from CCTV cameras and biomet- 
ric software to seismic-proof retrofitting of urban infrastructure. The importance of public-private partnerships in crisis management and urban security has been widely discussed in the literature. It has been argued that 'multi-stakeholder participation' enables effective responses to local disasters [Lewis and Mioch 2005: 51; Coaffee et al. 2009: 258] and a high level of 'response adaptability' [Booher and Innes 2010] and helps to mobilise urban resources with fragmented ownership [Chen et al. 2013]. Examples of public-private collaboration around the notion of urban resilience include the Cities Research Cluster at the Institute of Development Studies based in Brighton, the Singapore branch of the ETH Zurich Future Cities Laboratory, or the Future Cities Catapult based in London.

From technology to consultancy, the urban resilience domain is booming with companies like IBM, Arup, CISCO, Microsoft, Deloitte, or Siemens benefiting from this momentum. There has been a strong demand for smart city solutions based on surveillance technologies and mass real-time urban data collection. For instance, the IBM-designed 'control rooms' constantly monitor traffic, weather, or power cuts in a city [Singer 2012]. It has become a common practice for government authorities to outsource the implementation of 'resilience solutions' to private companies [Prior and Hagmann 2013]. However, the overreliance on surveillance technologies reduces urban security to a set of technical questions, avoiding the broader political dimension of who is a threat, who is to be secured, and how. In this context, the role of the private sector and its influence on public policy has been questioned. In major global cities such as New York City, the role of private corporations has grown to unprecedented levels in terms of urban social and spatial control [Mitchell and Becket 2008].

Be it as it may, academia has not been excluded from this process. Many scholars have taken a triple role in academia, policy advocacy, and corporate consultancy. Academic expertise from all sub-fields of urban and security research, including social and natural-oriented science, is drawn to policy-making on all levels, think-tanks, and, crucially, business. In this sense, advocacy is characterised by a relationship of dependence in both directions. This is because private companies need the expertise of scientists and researchers to attest to the quality of the services and products the companies are marketing. At the same time, experts from research and academia, always looking for alternative resources and funding, often produce outputs that are used for business objectives, in which case a careful balance of advocacy and science is required.

\section{Resilience in local politics and individual agency}

Resilience and the various programmes, organisations, and initiatives that bear its name can also be used for local political gain. Regardless of the critique from practical or political viewpoints, resilience is a term that 'sells' ideas and agendas of municipal and local officials and is often used for this purpose (M. Fernandez, in- 
terview, 10 October 2016). The objectives can include political prestige and power, which often come with participating in 'global' resilience initiatives, but they are also directed at 'branding' cities as resilient and smart, green, healthy, sustainable, and above all fit for investment [see Coaffee et al. 2009; Mitchell and Becket 2008]. Funding and the bargaining power that comes with it shape local government rationalities. The resources that local politicians gain from collaborating with resilience initiatives, projects, and organisations help them to maintain their political power and advance their agendas, regardless of how much these are aimed at benefitting their constituencies. They often prefer quick fixes, visible measures, and quantifiable solutions to complex urban problems. It has been argued that 'elected and appointed officials [tend to] be focused on short term and medium term aspects of their jobs to ensure retention of their positions' [Vale 2014: 199].

As much as resilience-labelled projects are often shallow, the discourse that accompanies them carries a powerful message about the behaviour of the individuals it seeks to 'empower'. In this context, resilience is also seen as a form of 'governmentality' that emphasises individual responsibility and requires constant preparedness and self-governance [Joseph 2013], and its objective is to govern the emergence of 'resilient populations' [Zebrowski 2013]. Individuals affected by disasters and environmental degradation are understood as 'inherently capable' of withstanding and overcoming whatever adversities they might experience. Needless to say that if they fail to do so, this is understood as a 'lack of will' on their part. One can see how it is not only the implementation of resilience that is outsourced from local governments and public officials; the same happens with the responsibility for failure, which now lies with communities and individuals.

Simply put, the resilience of a particular city and its population is much more than a neutral quality or attribute of a system or individual. On the one hand, it can be easily used for short-term political gain. On the other hand, it is profoundly political and sometimes invasive, especially in cases where a 'lack of resilience' is implied. This is because an absence of resilience legitimises external intervention. It is obvious how easily this essentially empty signifier can influence lives across entire cities. Resilience-labelled urban measures can be seen as undermining security of some people and populations rather than enhancing it [Coaffee and Fussey 2015]. In other words, resilience can 'contribute to (un) intended scientific justification of certain policies [and] depoliticise social change' [Olsson et al. 2017: 58].

\section{Resilience and social justice}

Much of the criticism directed at urban resilience is based on arguments about social justice. Focusing specifically on cities, scholars have argued that urban resilience itself raises many political questions: Who is to be 'made' resilient, by 
whom, using what measures, and to what purpose [Campbell 2004; Vale and Campanella 2005; Vale 2014]? While the preceding section addressed the legitimisation of interventions, this section focuses on the subjects of these interventions. The subjects tend to be non-resilient, typically poor communities and individuals. Their socio-economic standing renders them 'vulnerable' and thus in need of an external intervention. This typically takes the form of technical measures and 'training' initiatives in order to 'enable' these communities and individuals to realise their potential. Global investment institutions, such as the World Bank (followed by municipal and local officials in charge of resilience), tend to adopt this very approach and language when alluding to the 'vulnerable but unbreakable' nature of the urban poor enabled by specific measures such as micro-investment schemes [Hallegatte et al. 2016].

Social and environmental vulnerability, just like resilience, is highly specific. Cities tend to be profoundly unequal, and so is their topography of risk. The extent to which different people are exposed to 'environmental risk in a city [is often determined by] political interests and struggles over power that shape urban environment and society' [Pelling 2003: 4]. In this context, the quality and nature of 'resilience planning' exposes the 'relationship between the governments and the governed' [Vale and Campanella 2005: 352]. The effects of 'securing urban sites' at all costs can be wide-ranging, visible, and oftentimes disruptive for urban landscapes and populations. For instance, anti-terrorist measures are incorporated into the ways cities are designed and used [see Coaffee 2003]. The techniques and tools that similar policies called for are, however, often challenged on the grounds of privacy and justice. Surveillance of the urban public space can have profound effects in this sense [Lyon 2003], particularly the kind that is targeting specific, already marginalised urban communities [Coaffee and Fussey 2015].

Well beyond the anti-terrorism agenda, more chronic and structural challenges have also become subject to 'resilience' policies and interventions. In addressing urban crime, for instance, the role and purpose of the 'neoliberal', resilience-promising, crime-consulting industry has been questioned [Mitchell and Beckett 2008]. In the context of various security interventions labelled by resilience, it is clear that this catch-all phrase is not only immensely lucrative, but also 'politically exploitable' [Beilin and Wilkinson 2015: 1206].

\section{The value of resilience}

It is noteworthy that some authors do indeed see a certain potential and usefulness in urban resilience as a general principle or value for organising lives and systems. These hopeful views tend to be connected to certain conditions regarding the concept's use. For instance, resilience is seen as valuable as long as it is used as more than a catch-all phrase; that is, if it is used to challenge the existing political interconnections between the environment and society in cities, and 
thereby to bring about a systemic change [Vale 2014: 198]. A concept of 'critical resilience' has been proposed to highlight the emancipatory potential of resilience and to argue that the concept can indeed be a metaphor for change, when used to counteract neoliberalism instead of enabling it [DeVerteuil and Golubchikov 2016: 149].

While recognising the value of the cautiously optimistic arguments made in favour of resilience, as mentioned above, this paper remains sceptical of the potential of resilience to inform broader social and political change. The primary reason for this is that resilience has served the neoliberal project to a great extent and has consequently become a 'vague ideal' of what it claims to represent [Gleeson 2015]. This study therefore coincides with the view that resilience enables the status quo of the existing socio-political structures and in many ways serves their interests [see Cook and Swyngedouw 2012]. Secondly, resilience can also be used as a form of self-governing mechanism which, as argued before, poses questions about the very notions of human agency, freedom, and justice.

The paper argues that the powerful position resilience has gained within the discourse of the most relevant policy-making institutions and businesses has not and will not lead to a profound change in existing government and business rationalities. Resilience has captured and overtaken the previously championed notion of sustainability, which has costly social and environmental consequences. Preventing and reversing the urban effects of climate change has been replaced by an effort to adapt and mitigate them in situ. ${ }^{2}$ Needless to say that this is often done by and at the expense of communities and individuals whose ability to 'be resilient' in a technocratic sense is extremely limited. Making these communities 'responsible' for their own fate is not only cynical, but also hypocritical and morally unacceptable. The case study of Santiago contrasts the role of resilience as a policy buzzword on one side with its actual relevance and usefulness on the other-the contrast that is at the root of this paper's scepticism.

Regardless of the critique, resilience has gained a strong position within the fields of urban management, planning, and development throughout the last decade. There has been an increase in public and private demand for tools to secure cities that are facing a broad range of natural and human-induced risks. The notion of the 'risk society', which implies self-endangerment and transformation [see Beck 1992], has penetrated public discourse and policy and has legitimised all measures and tools necessary to 'secure' the populations and spaces 'against any conceivable threat' [Coaffee et al. 2009: 2]. Resilience has served as an incredibly broad discursive umbrella for a range of corporate products and services, as was suggested above. In this context, the purpose of the following section is to explore the most prominent 'urban resilience' initiative in recent years.

\footnotetext{
2 Some authors have argued that by 'giving up' on the issues of climate change and merely accepting and adapting to its effects, the very agency of the autonomous human subject is rejected [Schmidt 2013, 2015].
} 


\section{The Rockefeller Foundation and 100 Resilient Cities}

The paper critically interrogates the 100 Resilient Cities (hereinafter 100 RC) programme funded by the Rockefeller Foundation. This initiative used privately raised capital in order to create Resilience Offices and place them in the administrations of 100 member cities around the world. This is quite a unique project given its topic and scope, and yet a very successful one with regards to its global discursive impact. In this section, the purpose and principles of $100 \mathrm{RC}$ are explored before turning to a discussion of its practical implementation in the Metropolitan Region of Santiago since 2015. The case study focuses on the institutional setup that enabled this initiative, the role of private actors in defining Santiago's urban resilience agenda, and the interpretation of this process by public officials, academics, and civil society representatives.

The Rockefeller's 100 Resilient Cities programme is the focus of the case study, as it allows the paper to examine the significant interconnectedness between public and private sector in this field. $100 \mathrm{RC}$ connects local (municipal) administrations and mayors on one side, with a range of private sector providers on the other. The geographical span of the programme is truly global: it works with 100 cities all over the world focusing on three main trends affecting cities: urbanisation, globalisation, and climate change.

100 RC defines urban resilience as 'the capacity of individuals, communities, institutions, businesses, and systems within a city to survive, adapt and grow no matter what kinds of chronic stresses and acute shocks they experience' [Rockefeller Foundation 2017: 10]. This definition reflects the dominant understanding of resilience as a strategy to overcome the 'inevitable adversities' that come along with globalisation and climate change and its effects on cities and urban populations. It claims that 'chronic disasters' such as unemployment and environmental degradation will 'inevitably occur' [ibid.]. Leaving aside the questionable logic of lumping these conceptually distinct problems together with no further explanation, the adverse effects of climate change and globalisation are in no way tackled by $100 \mathrm{RC}$; rather, they are taken as a given. Instead of searching for possible ways to reverse them, the focus is on 'managing' them.

This approach legitimises (and openly advocates for) constant economic growth as the only possible way forward. In this understanding, free market activity (which 'inevitably' comes with adverse environmental and social impacts) becomes intertwined with human progress. One cannot be achieved without the other. The question that is asked is about 'how to manage' the adversities that will most certainly occur. The answer is to open the doors to entrepreneurs and citizens as the key forces of adaptation that will-unchained by regulations of the state-ensure constant progress. The increasing degree of private influence on issues of public policy is largely accepted-if not openly embraced-as a part of this equation.

Public-private collaboration is the essence of $100 \mathrm{RC}$ - and of the Rockefeller Foundation itself. Originally established in 1913, the Foundation's mission is 


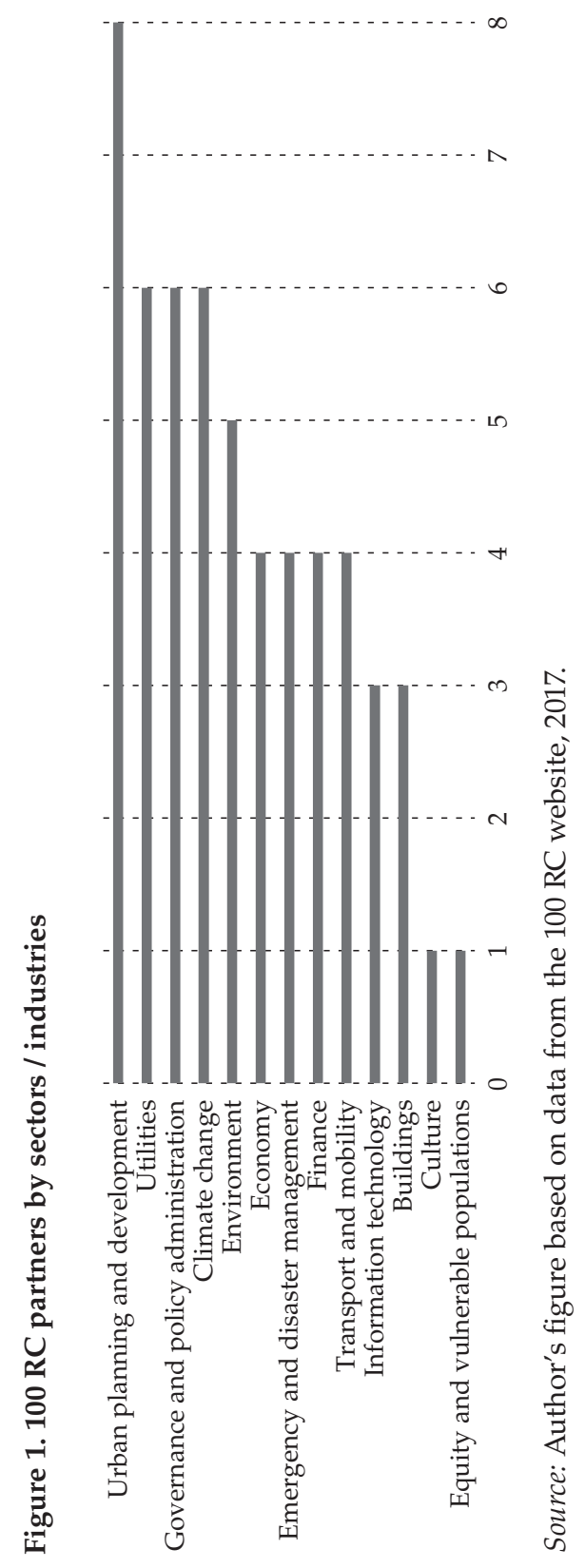


Figure 2. 100 RC partners by type of entity

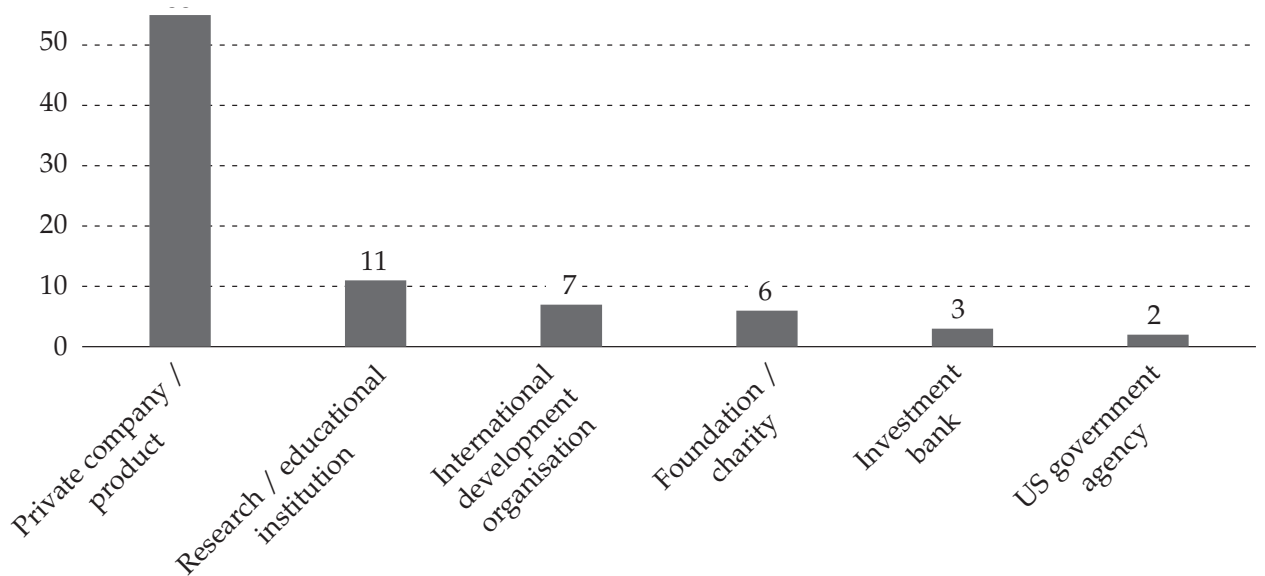

Source: Author's figure based on data from the 100 RC website, 2017.

to 'promote the well-being of humanity throughout the world' [Rockefeller Foundation, undated a]. 100 Resilient Cities was established as a non-profit organisation with a single programme objective that bears the same name. 100 RC was designed with the goal to 'help cities around the world to become more resilient to physical, social, and economic shocks and stresses' [ibid., undated b]. In addition to designing frameworks for resilience and appointing a Chief Resilience Officer for each city, the programme aims to link the cities with private-sector partners.

In order to assess and measure resilience, $100 \mathrm{RC}$ needed a broad assessment model or framework that could be applied to any urban system and yield 'measurable' results. To create a city resilience methodology, the Rockefeller Foundation commissioned Arup-a private multinational company focused on urban planning, design, management, and consulting, headquartered in London. The City Resilience Index was designed by Arup as a product, a service, and a methodology all in one. It has been used to assess and measure resilience of many of the 100 RC city members around the world, provided that their administrations were willing to purchase it (W. J. Simbieda, interview, 29 November 2016).

The importance of the programme partners of $100 \mathrm{RC}$ is evident in the way they are publicly promoted and in the way they are related to the program's functions [see Resilient Cities, undated]. Figure 1 above depicts the breakdown of the industries and sectors in which the total of 84 organisations operate. It includes the entities that are explicitly listed in these categories on the project website. The most salient industries are urban planning and development, utilities, climate change, and governance and policy administration (this includes companies that 
supply e-government technologies). Culture is represented by just one entity, while public health is not represented at all.

Looking at the RC 100 programme partners by type of entity, depicted in Figure 2, the overwhelming majority-almost two-thirds-are private companies or 'products' of private companies. These are followed by research or educational institutions (12.4\%) and international development organisations, some of which are NGOs $(8.6 \%)$. Programme partners also include foundations and charities and investment banks (above 8 and 7\%, respectively). Two US government agencies are also involved-namely, the US Department of Health and Human Services and the US Environmental Protection Agency.

Private sector involvement is a crucial part of this project-both in terms of its philosophical foundation and its practical implementation. While cities 'often lack the tools or technical assistance', the programme's private partners are eager to provide these. $100 \mathrm{RC}$ brings together a 'Platform of Partners, including global industry leaders and innovators [...] to respond to cities' demands and support them in taking action. We connect cities to Partners who have the solutions and expertise they need, and help catalyse the marketplace to create solutions' [Rockefeller Foundation 2017: 12, emphasis added].

Private 'Platform Partners' include major IT and insurance companies. One of the latter is SwissRe which designs tools to quantify hazard exposure and sells them to city administrations, claiming to be able to predict potential disasters' cost calculation. IT companies such as Palantir create systems to analyse and integrate massive streams of data collected in real time [Resilient Cities, undated]. These are in turn presented to the member cities as cutting-edge solutions to their complex socio-spatial problems. The funding available from the Foundation is then used by member cities to purchase these 'solutions', tailored to their specific needs.

The programme has been assessed by the Rockefeller Foundation as extremely successful in this sense so far: a $100 \mathrm{RC}$ project report from 2017 claims that more than 535 million USD has been 'leveraged from national, philanthropic, and private sources to implement resilience projects in member cities' [Rockefeller Foundation 2017: 13]. Critics of 100 RC point to the fact that the funds that member cities obtain are used to purchase consultancy services from the very sponsors of the Rockefeller Foundation (CIGIDEN researcher, interview, 28 November 2016), which does not exactly catalyse the local market, given that most of the $100 \mathrm{RC}$ private donors are large multinational companies.

Action taken within the framework of $100 \mathrm{RC}$ for each city member has four main components. First, a Chief Resilience Officer (hereinafter CRO) is appointed for each city. This is to provide 'logistical and financial guidance' and coordination for the project. The CRO is an official whose salary is paid by the Rockefeller Foundation for a year and who in the project materials is frequently referred to as a 'connector'. The CRO and their Office are placed within the structure of the local administration of each member city. In many cases, this is directly at City Hall, whereby a close relationship with the city mayor is established (P. Ottelini, 
interview, 9 June 2016). In other instances, CROs have been placed elsewhere within the structure of the local or municipal administration (depending on the administrative model of any given city). The CRO counts on financial support exceeding 1 million USD throughout the first year and acts as the facilitator of the resilience project in their city.

Second, a City Resilience Strategy is developed as one of the most important project outputs. The 'participatory process' of creating the Strategy is supposed to last from 6 to 9 months, ${ }^{3}$ at the end of which a strategic document is presented. It defines the main vulnerabilities and risks that the city faces and suggests a set of goals and priorities for future action. These documents tend to be fairly detailed and specific about the problems they identify and the solutions they propose. The city's CRO and her team are the main driving force behind the publication of a City Resilience Strategy.

Third, direct connections are facilitated between the cities and the Platform Partners of $100 \mathrm{RC}$, two-thirds of which are private companies, as was shown above. It is important to note that many of the main 100 RC partners are multinational companies, as opposed to locally based enterprises. When speaking about the resilience of cities and city regions, officials often refer to the need of 'making local economies strong' in order to face shocks and stresses (A. Johnson, interview, 23 September 2015). However, the role of local companies is not particularly salient in the 100 RC Resilience Strategies, except for a basic supply level. As the urban resilience market becomes more globalised, local and smaller companies are often pushed aside as they cannot compete with the multinational 'resilience providers' that partner with the Rockefeller Foundation and thus have direct access to the member cities' administrations.

Finally, 100 RC facilitates mutual networking among the member cities in order to promote 'best practices'. This is typically done at $100 \mathrm{RC}$-sponsored international conferences, workshops, and seminars during which member cities present their Resilience Strategies, discuss the challenges their cities face, and learn about practices used in other member cities. The private project partners and other sponsors have access to these meetings as well, and this is where important connections are made that then lead to public-private collaborations in concrete cities under the umbrella of 'urban resilience'.

The following section discusses the way $100 \mathrm{RC}$ has been introduced and implemented in the case of Santiago Metropolitan Region (hereinafter SMR). The

\footnotetext{
${ }^{3}$ Although the period of 6 to 9 months is the standard period prescribed as necessary to draft the Strategy, in some instances this process takes years to complete. This is owing to different political priorities and resource allocation, which tend to change over time and are to a large extent affected by political and personnel changes resulting from municipal elections. The City of Barcelona, for example, became a 100 RC member city in 2014, and subsequently created a Department of Resilience on the level of the Municipal Office (Ayuntamiento). Despite the long-declared conceptual work on the City's Resilience Strategy, the document has yet to be published.
} 
empirical material used in this section comes primarily, but not exclusively, from on-site fieldwork conducted in SMR throughout November 2016. This included collecting relevant written materials and conducting interviews with multiple representatives of the city administration, universities, and non-governmental organisations. ${ }^{4}$

\section{Rockefeller in Chile: Resilient Santiago}

As this section will discuss, Santiago's urban resilience experience is largely defined by formal declarations and discourses. The success of the Rockefeller project's practical implementation, however, has been repeatedly questioned by the very stakeholders that it claims to include in the 'resilience initiative'. While the latter widely employs the language of community participation and empowerment, the practices that are legitimised on its behalf reinforce the existing status quo. Urban resilience is understood and enacted through a 'project management' lens-a complex, but largely top-down initiative coordinated by the Rockefeller-sponsored Resilience Office, with a set of material goals, benchmarks, and deadlines, and an outline of smaller projects assigned to project partners and subsidiaries. This is complemented by 'outsourcing the responsibility' for its implementation to private sector and urban communities. In this process, a broader issue of extreme socioeconomic inequality in Santiago is largely ignored, let alone challenged.

To be sure, the $100 \mathrm{RC}$ project is not the sole actor responsible for adopting 'resilience' to maintain and advance the existing political and economic structures in Chile. International organisations and the Chilean National Government have had an important role in preparing the institutional and discursive conditions in which the 'resilience enterprise' now thrives. As argued throughout this article, resilience has been deployed in ways that strengthen and legitimise the inherently neoliberal socio-economic structures in Chile. This provides certain clues about the largely sceptical attitude that exists to resilience, which becomes apparent in discussions with representatives of civil society and academia in Santiago, ${ }^{5}$ as will be shown below.

\footnotetext{
${ }^{4}$ In several cases, the names of the interviewees are not specified in the text, referring to them rather by their general affiliation. This is in an effort not to jeopardise their professional positions with regards to the critical remarks they make towards their funding government agencies and private entities.

${ }^{5}$ A closer look at perceptions of neoliberalism among university students in Chile indicates a strongly unfavourable attitude to the term, which is in their view connected with inequality, injustice, and individualism. A quantitative study along these lines was published in 2013 by Mendez-Ramirez.
} 
Resilience discourse first appeared in Chile in the context of disaster risk reduction initiatives led by UN-based organisations. The 2005 Hyogo Framework that introduced a ten-year global plan for action focusing on risk reduction mentioned resilience 19 times [UNISDR 2005]. While Chile was a signatory to this document, the country still lacked the structure for strategic planning in this regard, and not many practical steps were taken towards implementing the Hyogo objectives (G. Castillo, interview, 14 November 2016). Mid-way through the Hyogo implementation period in 2010, an 8.8 earthquake struck central Chile and rocked buildings in the capital, which reportedly prompted government officials to focus on disaster risk reduction [ibid.]. In March 2015, Chile signed the abovementioned Sendai Disaster Reduction Framework that establishes the objectives for 2015-2030, with a strong emphasis on the concept of resilience and on the role of the private sector in resilience-building. This was the moment when resilience truly took off in the Chilean discourse, trickling down from international organisations to the central government and relevant ministries, which started using the concept to refer to many ongoing initiatives, from social inclusion campaigns to emergency response. Resilience also became a buzzword in research and development efforts on the national level, with a document titled Resilient Chile in the Face of Natural Disasters, published in December 2016 [CNID 2016].

Along with these developments, the involvement of private sector in the 'resilience surge' started to be more apparent. This was done in two ways: First, many global companies incorporated resilience into their corporate linguistic expressions, with mid-range and smaller companies following suit. Second, Chilean government-led initiatives labelled by resilience openly reached out to the private sector in order to include it in new 'resilience' programmes and platforms. One of the most prominent examples was the establishment of SeCRO-Empresas por la Resiliencia (Companies for Resilience) in 2015, whose mission was to define the role of private businesses in building resilience. SeCRO includes major companies from industries such as electric power, water management, infrastructure, mining, and communications [SMR 2017: 193]. Soon enough, the Chilean private sector discovered the potential of resilience as a discursive tool to enhance their corporate visibility and access to policy-making.

\section{Resilience between state, regional and local politics}

In this context, it was more a matter of time before global 'resilience' philanthropies started operating in Chile. After a proposal designed by a group of Chilean architects studying at Harvard University [Uribe 2014], Santiago Metropolitan Region (hereinafter SMR) was announced as a new 100 Resilient Cities member in June 2015. This was followed by a mix of pride and anticipation in the local press [see Pérez 2015; PES 2015, 2020]. At the same time, Chilean emergency management officials were questioning the appropriateness of 'choosing the entire Region as the resilient city member' (ONEMI official, interview 28 November 2016). This is 
due to the administrative complexity of the region, which is made up of 52 communes that are largely independent in terms of the day-to-day implementation of any policies proposed on the Regional level [see Gobierno de Chile 2011]. This creates a somewhat fragmented governance model with a lack of coordination and comprehensive planning. ${ }^{6}$

In other words, critics argue that the $100 \mathrm{RC}$ project was placed with an administrative authority that is too detached from the daily struggles of the 52 Communes of the Metropolitan Region (National emergency official, interview, 28 November 2016). Others have argued that there are many remote areas in Chile that are much more exposed to natural risks (such as tsunamis) and that 'these vulnerable communities deserve more attention' than the relatively wealthy and well-serviced capital city (A. Parra, public lecture, 18 November 2016). Still, the decision was made by the Rockefeller Foundation to make SMR a member, mainly because it has the desired organisational and economic attributes that the project seeks. That is, the Metropolitan Region includes and provides access to a network of powerful stakeholders, be it in public administration or key industries and private companies.

Also, placing the Resilience Office directly under the Regional Government was a matter of personal prestige for the then Governor (Intendente) of SMR Claudio Orrego. A member of the Christian Democratic Party, former Minister of Housing and Mayor of Peñalolén Commune, Mr Orrego unsuccessfully ran for the Presidential office in 2013 and lost to Michele Bachelet. He was then nominated for the position of the Governor in 2014. $100 \mathrm{RC}$ was the most prestigious global programme focused on cities under his leadership, and it gained an important role in branding Santiago as a global city 'fit for investment', and a matter of personal pride (ONEMI official, interview 28 November 2016). Mr Orrego has not explicitly stated he would run for the Presidential office again in 2021; however, political commentators have stated this is possible [LA Network 2018].

The position of Santiago's Chief Resilience Officer was assigned to Gabriela Elgueta in January 2016 [Resilient Cities, undated]. Mrs Elgueta, who was formerly employed by the Ministry of Defence as a project coordinator and at the Municipality of Santiago as Director of Urban Planning, now also simultaneously serves as director of Resilience on SMR government level. This illustrates the extent of overlap between the essentially public offices that Mrs Elgueta has held, and the privately funded 100 RC Resilience Officer role. In charge of set-

\footnotetext{
${ }^{6}$ For instance, the National Civil Protection plan states that Santiago's 52 communes are not obliged, but should act in cases of civil protection [Gobierno de Chile 2002, emphasis added]. Communes' actions are rather ad hoc, based on any given emergency, and often cite a 'lack of funds to carry out effective strategic planning' (Santiago commune official, interview, 16 November 2016). This approach is reflected in the staffing of the central Santiago commune's Emergency and Civil Protection Department, which has 50 staff working on ad hoc emergencies, with only 3 staff dedicated to longer-term strategic planning [ibid.].
} 
ting the priorities and solutions to the governance of Santiago, she finds herself closely collaborating with key private companies and donors connected to $100 \mathrm{RC}$ project. The continuation of the Resilient City project, once the one-year funding package is exhausted, largely relies on the willingness of the SMR, along with the corporate partners, to take over the responsibility of funding-with whatever conditions that may apply. The Executive Director of the Resilient Santiago project, and a close collaborator of Mrs Elgueta, Cristian Robertson, emphasised the challenges of funding and project execution. The need to ensure a post-2016 continuation of the project was paramount; in any case, the funding ground for resilience in Santiago looked relatively fruitful, as 'many funds focus on cities at this moment and the resilience concept helps to secure this funding' (C. Robertson, interview, 23 November 2016). This appears to be an opportunity for various private donors to fill in a void.

The process of crafting the Resilience Strategy of Santiago Metropolitan Region (hereinafter, the Strategy) began in the summer of 2015 and took almost two years. The document was eventually published in March 2017. Perhaps not surprisingly, given that the Resilience Office is located on the level of the Government of SMR, there is a strong argument advanced in the Strategy to make the regional government more powerful and responsible. It argues that critical resources, transport, planning, and the budget should all be coordinated by the regional government [SMR 2017: 40].

It also lists the main pillars that are to guide the project: urban mobility, environment, security, risk management, economic development, and social equity [ibid.: 59]. The question of social vulnerability is addressed in several instances throughout the Strategy; however, the principal threats are still seen to be the ones of natural origin-earthquakes, volcanic eruptions, extreme hydro-meteorological events, floods, or forest fires [ibid.: 29]. Less attention is paid to chronic stresses such as urban poverty and inequality, despite the fact that more than $20 \%$ of SMR inhabitants found themselves in conditions of 'multidimensional poverty' in 2015 [Gobierno de Chile 2016: 20].

Chile has traditionally been and continues to be a profoundly unequal country in terms of social and economic development. According to an OECD report from 2015, Chile exhibits the highest inequality and poverty rates among OECD countries [OECD 2015: 3]. When exploring these variables on the level of the Metropolitan Region, sharp income inequality comes to light. In 2017, a visual representation of poverty on the level of the SMR was published in the form of a map that clearly highlighted areas with household income below 300000 Chilean pesos (equivalent to of 392 Euros) per month. These are scattered across the Metropolitan Region, mostly in its eastern part [El Desconcierto 2017]. Poor areas suffer from lower-quality infrastructure and public transport, and their inhabitants often rely on the informal economy to make ends meet. Their 'invisibility', or the lack of political attention given to them, seem to be overcome only in the run-up to local elections, when material incentives are promised in return for 
political support. ${ }^{7}$ The dominant economic model, along with a traditional clientelistic approach, connections between national and municipal public officials and corporate elites, and socio-economic inequality have largely persisted. This state of affairs has been widely criticised, especially by the academic community in Santiago, as will be shown below.

\section{The centrality of private actors in resilience programmes}

Inequality seems to pose a challenge for the entire Metropolitan Region. Yet, the 'resilient' practices designed for Santiago follow a narrow, mostly technocratic logic, without challenging the economic model that reproduces the existing urban poverty. The resilience of the city is largely equated with the resilience of its economy, especially on the level of business. The Strategy consistently ties Santiago's resilience capacity to the condition of the private sector. It lists several public-private platforms and specific companies that participated in the Strategy's elaboration. The latter include the Rockefeller programme partners-Arup, Ernst \& Young, Veolia, and RMS, in addition to the Chilean private sector represented by Aguas Andinas, CGE, Telefonica, Transbank, Abertis, COPEC, GNL, and Metrogas [SMR 2017: 49].

Many critical utilities in Santiago are completely privatised, such as Aguas Andinas, which operates the water system, and Chilelectra, which manages the electric power supply. The logic that guides their operations is 'very much efficiency focused in order to maximize profit', which makes it difficult to accept the broader understanding of resilience employed by researchers (F. Rivera, interview, 25 November 2016). The language of the 'business continuity' seems to be the most powerful way in which to draw companies into discussing resilience with public officials and civil society [ibid.]. In other words, businesses participate because resilience is adaptable enough to fit their strategic interests, in terms of both profits and the influence over public policy. Platforms for 'resilient practices' and 'resilience-building' have brought together private companies, on one side, and public authorities, ranging from the ministries to the metropolitan re-

7 This phenomenon is not unique to Santiago, especially considering the context of major cities of Latin America. Nor can it be argued that the inequality referred to is the product of the economic downturn of the last decade. Inequality is a historically significant constant for Chile, while household income is only one of many indicators, others being the quality of education and health care provided to the population. In 1973, the social programmes of Salvador Allende were cut short by the coup that brought Augusto Pinochet to power. This started a gradual process in which the Chilean economy came to be dominated by neoliberal ideas, which, to a large extent, survived long after the dictatorship ended in the late 1980s. In any case, the fruits of the national economic growth experienced by Chile in recent decades do not appear to have trickled down equally into communities, despite numerous social policies advanced by the two administrations of Michele Bachelet. 
gion and its communes, on the other. It is the interconnection between the SMR, the communes, and private companies that is of much interest to the 100 RC Strategy for Santiago.

Connected to a broader issue of managing urban crime, public security is one of the declared priorities of the Regional Government. This is to a large extent due to the importance that this issue assumes in public (i.e. voter) perception [see SMR 2017: 104]. While the Strategy mentions different projects focused on community participation and public spaces [ibid.: 111], the actual means it suggests to tackle urban crime are predominantly technocratic. This includes advocating for installing vast CCTV systems to monitor activity and movement citywide and integrating imagery from both publicly and privately operated cameras [ibid.: 115].

Bridging public security with private industry does not end there. The Strategy calls for broader cooperation between public and private security providers in Santiago [ibid.: 118]. This is perhaps not surprising given the extent of the private security operations in a city characterised by such sharp inequalities. The technological capacity of the private sector is something that appeals to the Regional Government calling for integrated information systems, sophisticated risk-mapping software, and social media monitoring [ibid.: 128-129]. This is where private companies come into the picture as actors that can provide external resources and, at the same time, pursue their corporate interests.

In short, the private sector is 'the key part in the process of constructing resilience' [ibid.: 150] and companies do realise how their interests relate to the priorities of the Regional Government. At the same time, the private sector is offered a helping hand by the proponents of the Strategy. Reflecting the current corporate language in the field of urban planning and development, the Strategy uses concepts such as building a 'Santiago brand' or 'smart city' [ibid.: 156]. In the meantime, the critics point out that for businesses, 'resilience equals continuity of their operations, and protection of their investments' (PUC university professor, interview, 28 November 2016). The private sector plays a key part of the urban resilience network of Santiago in terms of discourse and material resources.

The following section discusses the interpretations of the process described above put forth by 15 experts who were interviewed between 2015 and $2016 .{ }^{8}$ Structured, open-question interviews were conducted with several senior academics from the University of Chile and Pontifica Universidad Catolica. In addition, members of Chilean CIGIDEN research centre for the study of natural disaster risk and the National Emergency Management Office (ONEMI) were also interviewed. Some respondents are referred to by using their approximate professional positions, instead of their real names, as in the case of a local NGO that has worked with poor communities and a Santiago commune official who spoke about organisational deficiencies on the level of local governance.

\footnotetext{
${ }^{8}$ This includes the interviews with additional officials referenced previously in the text.
} 


\section{Resilience and civil society}

The Santiago Resilience Strategy claims to have engaged all the major stakeholders-public and private-that are involved in managing the city's resilience in one way or another [SMR 2017: 48]. However, the quality and nature of this involvement have been questioned by some of these very stakeholders. According to a Central Santiago Commune official, 100 RC meetings that involved all 52 communes of Santiago did not go beyond a 'mere presentation of the project and its goals'. At the same time, there was no substantial review of the issues and risks that the communes themselves perceive as crucial. For example, a Santiago Commune official interviewed recalled that one of the 'exercises' focused on the effects of heavy rains, while she maintained that 'rain is not really a problem in Santiago-we have much more important risks to deal with' (Santiago Commune representative, interview, 16 November 2016). Before the Santiago Resilience Strategy was published, several workshops were organised; however, the specific risks and issues that these addressed were seen as rather irrelevant for some communes [ibid.].

The above suggests that, as I argue, the 100 RC urban resilience experience of Santiago is primarily defined by a top-down approach. Despite the existing discourse that builds on terms like community participation and capacity building, projects continue to be managed in a way that does not allow much input from the communes, which is again evidence of the disconnection between the SMR and the communes discussed above. The relevance and usefulness of this project for Santiago residents is therefore called into question. As for urban communities-especially the vulnerable and marginalised ones-the Strategy treats them as subjects of policies and measures, but it seems their input was not taken into consideration to any great extent. The Strategy lists ten projects within its Equity pillar, but they are limited to short-term education and integration programmes for youth [see SMR 2017: 160-177]. This seems somewhat insufficient given the complex nature of the urban problems faced by many marginalised communities in Santiago.

Urban resilience as understood and enacted by 100 RC therefore barely considers systemic inequalities that have trapped many communities and individuals in a state of vulnerability. In this sense, an interview with a regionally focused NGO representative deserves to be quoted at length: 'in discourse that is based on World Bank's understanding of resilience, the state sides with private interest-resilience and development is understood as resilience of business [emphasis added]. When we talk about resilience, it is a mission accomplished in terms of discourse-but in reality, the community representatives are not invited to the table when it comes to implementation ... We are seen as problematic actors by the state, as the state sees eye to eye with private business' (NGO representative, interview, 28 November 2016).

Despite this impression, the 100 RC Strategy emphasises a human-centred approach to the point of including it in its title. It also cites the 'right to the city' 
concept [SMR 2017: 100], originally proposed by a Marxist geographer named David Harvey as 'individual liberty to access urban resources' - a profoundly emancipatory approach to urban development that is fundamentally critical of the dominant economic model [see Harvey 2008: 23]. References to this concept are at odds with the technocratic problem-solving logic that informs the Strategy. In other words, using the 'right to the city' concept to give deeper meaning to a clearly neoliberal project is highly ambiguous, especially given the political and philosophical foundation of Harvey's work. The persistent inequality that defines Santiago Metropolitan Region is mentioned in the Strategy; however, it is merely declared as the state of affairs, but the structures upon which it is built are left unquestioned. This is why the use of the 'right to the city' concept appears to be profoundly inadequate, if not cynical.

In addition to the lack of emancipatory focus of $100 \mathrm{RC}$, academia has raised questions about the practical impact of the project. Several urban researchers and academics from a major Chilean university expressed highly sceptical views in this regard. Resilience is seen as yet another trendy concept, like many other ones before- ' 'green, sustainable, ecological, healthy, smart ... and the latest one is resilient ... [The Rockefeller Foundation] works with formal institutions and actors, but brings it into a context where many parts of the city, economy and life are informal - this is all disregarded and ignored' (J. P. Sarmiento, interview, 18 November 2016). The role of the private sector in policy-making is also seen from a critical perspective. 'What we have now in urban planning is accommodating private developers' interests within the election cycle of local administrations ... This planning is in many cases in a sharp contrast with any reasonable considerations of actual topography of risk [in Santiago]' [ibid.].

The feasibility of the $100 \mathrm{RC}$ leaders being able to coordinate all the necessary actors is also questioned. The difficulty of designing coherent policies across the 52 individual communes of Greater Santiago was already mentioned as being a major hindrance. The current institutional and legislative set-up simply does not allow for implementing measures effective for the city as a whole, no matter how well intentioned these may be. Each commune, for instance, has its own Emergency Management Office, which deals with innumerable issues relating to public security, that is, the resilience of the commune and its population. 'The [Santiago Regional Government] Resilience Department is an Office, with a Chief Resilience Officer who is named by an external [Rockefeller Foundation] institution, how can they claim to be able to coordinate resilience of a Metropolitan Region as big as this one? It is a good intention, but it cannot really work in the long term, as many urban development policies are needed that can only be led by the Ministry of Housing [of the National government]' (C. P. Castro, interview, 18 November 2016; emphasis added). Despite the persistent criticism of the Strategy and the Office behind it by Chilean academia, the latter is portrayed in the document as a key actor that has been consulted since the early stages of the 100 RC project [SMR 2017: 48]. 


\section{The meaning of resilience}

The above discussion suggests that $100 \mathrm{RC}$ has employed a largely top-down project management approach based on planned programmes and initiatives with a limited time-frame and budget. While employing the discourses of community empowerment and participation, it also advocates for 'specialised interventions' in 'highly complex' neighbourhoods [SMR 2017: 175]. This is accompanied by an emphasis on the key role of the private sector and the 'outsourcing' of much of the responsibility for urban development and security. This reproduces the network of government agencies acting as the coordinators and facilitators who define the objectives and private businesses acting as developers and solution providers.

In addition to this, resilience has also served the Chilean government as a way of replacing the previous discourse of sustainability. It appears that 'as a result of the current development model, [Chile and Santiago has] tremendous environmental problems that are displacing entire communities' (NGO representative, interview, 28 November 2016). National and Regional Government representatives now realise that 'their development model is not sustainable, and therefore they use resilience politically, in order to place the responsibility for failure on communities and individuals' (PUC university professor, interview, 28 November 2016). In addition, resilience and the international initiatives that bear its name can also be wielded as tools of political leverage and prestige in local politics.

What does resilience mean in this context? What new effects does it actually introduce? It has been used more as a two-faced concept. On the one hand, it 'gives agency to communities, which can appear as a good thing [and on the other hand,] it is extremely neoliberal, in a way that it puts the government into a "coordinator" role and leaves the implementation largely to the private sector and the communities themselves' (PUC university professor, interview, 28 November 2016). The problem is that this approach does not consider the context of social vulnerability and inequality. It implies that 'anyone who has enough willpower can be resilient-however, some people's resilience capacity is undermined from the start by the structural conditions they find themselves in' [ibid.; emphasis added]. This corresponds to the view that 'resilience perspective is no less rigorous in its selective function than Darwinian revolution' [Walker and Cooper 2011: 156]. Santiago continues to be characterised by sharp income inequalities and social and spatial segregation [Fuentes et al. 2017: 95], and the 'urban resilience' push, accompanied by discourse used for short-term political purposes, is unlikely to bring about change in this regard.

\section{Conclusion}

Resilience has become a discursive principle that governments and the public sector employ to deal with the shortcomings of the dominant development model. Urban resilience represents a new discursive and practical tool for the private 
sector to influence policy-making by directly connecting with local administrations. Far beyond the expertise and capacities of local governments, the operation of urban infrastructures is largely placed in private hands. At the same time, neither the Santiago Metropolitan Government nor the private companies included in the Resilient Santiago project have publicly admitted that corporate solutions, however customised they may be, are unlikely to address social, political, and economic challenges inherently present in the city. Therefore, these products are far from being universal solutions able to deal with complex vulnerabilities. Furthermore, the privatisation of public security-related functions, including massive urban data collection and surveillance, raises important questions about accountability and public interest.

The first objective of this paper was to offer a critical conceptualisation of urban resilience, and thereby challenge the dominant perspective in urban policy that understands resilience as an apolitical, problem-solving tool. It also examined the issue of the 'agency' of local populations in the context of their will versus the means to be resilient. The second objective was to offer a contribution to the existing critical literature on urban resilience, which takes a sceptical view of the relevance and impact of this policy buzzword. Against the backdrop of the cautious optimism expressed by some authors, this paper has argued that resilience has turned into a rather empty signifier for solving the existing problems of cities and urban populations. It has, at the same time, become powerful on a different level, which is as a mechanism of self-governance. It has helped governments and other organisations to evade the responsibility for poor planning and policies and instead it places this responsibility with (more or less) resilient urban subjects. In practice, this has led to a systematic disregard of some pressing social and economic issues that exist in the case of Santiago and that are applicable to scores of other cities around the world.

The purpose of the case study was to offer unique empirical insight into the 'urban resilience' momentum in the Santiago Metropolitan Region. Tracing the relevant actors illustrates how resilience discourse emerged in the 2010s and has since then penetrated the policy frameworks and business strategies of numerous stakeholders from the international to the local level. It also highlights the way in which resilience was installed in a top-down manner by central government agencies, the Regional Government and the Rockefeller Foundation and then operated in a trickle-down process. While corporate actors have been able to adapt and tap into this momentum, many others continue to miss out.

There appears to be a consistent sceptical or outright critical view of the contribution of the 100 Resilient Cities project to Santiago. First, resilience is seen as a convenient substitute for sustainability, which was largely incompatible with the neoliberal logic of constant growth and economic profit. Second, resilience has become a buzzword used for local political ends, but it remains an empty signifier unless the broader underlying issues are addressed. These include the question of extreme socio-economic inequity on the one hand and a lack of long-term urban planning and development on the other. While Santiago can be 
regarded as one of the leaders of urban resilience discourse in Latin America, there is a tremendous gap between the rhetoric and the implementation of what resilience claims to be in this context-a state of inclusiveness, justice, and development that works for all.

KATARína SvitKové is a PhD candidate in International Relations in the Department of Security Studies of the Institute of Political Science, FSS, Charles University in Prague. She completed her master's degrees in Security Studies at Charles University and in Strategic Studies and International Security at the University of Granada in 2014. Her research builds on a critical approach to human security in the context of city governance and issues of urban vulnerability and resilience. From 2011 to 2012 she worked at the Institute of International Relations in Prague. In addition to academic research and teaching, she has worked in the field of international university education.

\section{References}

Alexander, D. 2013. 'Resilience and Disaster Risk Reduction: An Etymological Journey.' Natural Hazards and Earth Systems Sciences. 13: 2707-2716, https://doi.org/10.5194/nhess-13-2707-2013.

Beck, U. 1992. Risk Society: Towards a New Modernity. London: SAGE Publications.

Beilin, R. and C. Wilkinson. 2015. 'Introduction: Governing for Urban Resilience.' Urban Studies 52 (7): 1205-1217, https://doi.org/10.1177/0042098015574955.

Booher, D. and J. Innes. 2010. 'Governance for Resilience: CALFED as a Complex Adaptive Network for Resource Management.' Ecology and Society 15 (3): article 35, https://doi.org/10.5751/ES-03404-150335.

Bourbeau, P. 2017. 'Resilience, Security and World Politics.' Pp. 26-37 in The Routledge Handbook of International Resilience, edited by D. Chandler and J. Coaffee. New York: Routledge.

Campbell, H. 2004. 'Cities and the Future: Resurgence and Resilience?' Planning Theory \& Practice. 5 (3): 369-371, https://doi.org/10.1080/1464935042000257332.

Chen, J., T. H. Yun Chen, I. Vertinsky, L. Yumagulova and C. Park. 2013. 'Public-Private Partnerships for the Development of Disaster Resilient Communities.' Journal of Contingencies and Crisis Management 21 (3): 130-143, https://doi.org/10.1111/1468-5973.12021.

Coaffee, J. 2003. 'Recasting the "Ring of Steel": Designing out Terrorism in the City of London?' Pp. $276-296$ in Cities, War and Terrorism: Towards Urban Geopolitics. Oxford: Blackwell Publishing.

Coaffee, J. 2009. Terrorism, Risk and the Global City. Towards Urban Resilience. Burlington: Ashgate.

Coaffee, J. and P. Fussey. 2015. 'Constructing Resilience through Security and Surveillance: The Politics, Practices and Tensions of Security-Driven Resilience.' Security Dialogue 46 (1): 86-105, https://doi.org/10.1177/0967010614557884.

Coaffee, J., D. M. Wood and P. Rogers. 2009. The Everyday Resilience of the City: How Cities Respond to Terrorism and Disaster. New York: Palgrave Macmillan, https://doi.org/10.1057/9780230583337. 
Consejo Nacional de Innovacion para el Desarollo (CNID). 2016. Hacia un Chile Resiliente Frente a Desastres: Una Oportunidad. Santiago: CNID.

Cook, I. and E. Swyngedouw. 2012. 'Cities, Social Cohesion and the Environment. Towards a Future Research Agenda.' Urban Studies 49 (9): 1959-1979, https://doi.org/10.1177/0042098012444887.

DeVerteuil, G. and O. Golubchikov. 2016. 'Can Resilience Be Redeemed?' City 20 (1): 143-151, https://doi.org/10.1080/13604813.2015.1125714.

El Desconcierto. 2017. 'El mapa que muestra como se distribuye la brutal desigualdad en Santiago. Online El Desconcierto.' Retrieved 4 April 2017 (http://www.eldesconcierto.cl/2017/04/04/el-mapa-que-muestra-como-sedistribuye-la-brutal-desigualdad-en-santiago/).

Friend, R. and M. Moench. 2013. 'What Is the Purpose of Urban Climate Resilience? Implications for Addressing Poverty and Inequality.' Urban Climate 6: 89-113, https://doi.org/10.1016/j.uclim.2013.09.002.

Fuentes, L., O. Mac-Clure, C. Moya and C. Olivos. 2017. 'Santiago de Chile. Ciudad de ciudades? Desigualdades sociales en zonas de mercado laboral local.' Revista de CEPAL 121: 93-109, https://doi.org/10.18356/ed9f7bc0-es.

Gleeson, B. 2015. The Urban Condition. New York: Routledge.

Gobierno de Chile. 2002. Plan Nacional de Proteccion Civil. Decree 156/2002. Retrieved 17 November 2018 (http://www.leychile.cl/Navegar?idNorma=199115).

Gobierno de Chile. 2011. Regiones, Provincias y Comunas de Chile. Subsecretaria de Desarrollo Regional y Administrativo. Retrieved 17 November 2018 (http://www. subdere.gov.cl/documentacion/regiones-provincias-y-comunas-de-chile).

Gobierno de Chile. 2016. Informe de Desarrollo Social 2016. Ministerio de Desarrollo Social. Retrieved 17 November 2018 (http://www.ministeriodesarrollosocial.gob.cl/ pdf/upload/Informe_de_Desarrollo_Social_2016.pdf).

Hallegatte, S., A. Vogt-Schilb, M. Bangalore and J. Rozenberg. 2016. Unbreakable: Building the Resilience of the Poor in the Face of Natural Disasters. Washington, DC: The World Bank.

Harvey, D. 2008. 'The Right to the City.' New Left Review. 53: 23-40.

Hooling, C. S. 1973. 'Resilience and Stability of Ecological Systems.' Annual Review of Ecology and Systematics 4: 1-23, https://doi.org/10.1146/annurev.es.04.110173.000245.

Jacobs, B. 2005. 'Urban Vulnerability: Public Management in a Changing World.' Journal of Contingencies and Crisis Management 13 (2): 39-43, https://doi.org/10.1111/j.1468-5973.2005.00454.x.

Joseph, J. 2013. 'Resilience as Embedded Neoliberalism: A Governmentality Approach.' Resilience: International Policies, Practices and Discourses 1 (1): 38-52, https://doi.org/10.1080/21693293.2013.765741.

LA Network Editors. 2018. Claudio Orrego: La politica en la sangre. LA Network. 4. February. Retrieved 30 November (http://la.network/claudio-orrego-politica-la-sangre/).

Lewis, D. and J. Mioch. 2005. 'Urban Vulnerability and Good Governance.' Journal of Contingencies and Crisis Management 13 (2): 50-53, https://doi.org/10.1111/j.1468-5973.2005.00456.x.

Lyon, D. 2003. Surveillance after September 11. Oxford: Polity.

Mendez-Ramirez, O. 2013. 'Neoliberalismo y equidad: la sociedad chilena analizada desde una perspectiva estudiantil.' Revista Iberoamericana de Educacion Superior 4 (11): 3-25.

Metzger, P. and J. Robert. 2013. 'Elementos de reflexión sobre la resiliencia urbana: Usos criticables y aportes potenciales.' Territorios 28: 21-40. 
Mitchell, K. and K. Beckett. 2008. 'Securing the Global City: Crime, Consulting, Risk, and Ratings in the Production of Urban Space'. Indiana Journal of Global Legal Studies 15 (1): 75-99, https://doi.org/10.2979/gls.2008.15.1.75.

Olsson, L., A. Jerneck, H. Thoren, J. Persson and D. O’Byrne. 2017. 'A Social Science Perspective on Resilience.' Pp. 49-62 in The Routledge Handbook of International Resilience, edited by D. Chandler and J. Coaffee. New York: Routledge.

Organisation for Economic Cooperation and Development (OECD). 2015. Chile: Policy Priorities for Stronger and More Equitable Growth. OECD, September 2015. Retrieved 15 November (https://www.oecd.org/chile/chile-policy-priorities-for-stronger-andmore-equitable-growth.pdf).

Organisation for Economic Cooperation and Development (OECD). Undated. 'Resilient Cities. Regional Development.' Retrieved 17 November 2018 (http://www.oecd.org/cfe/regional-policy/resilient-cities.htm).

Pelling, M. 2003. Vulnerability of Cities: Natural Disasters and Social Resilience. London: Earthscan.

Pérez, N. 2015. 'Fundacion elige a Santiago como una "Ciudad resiliente".' Diario Libre, 1. July. Retrieved 20 Novermber 2018 (https://www.diariolibre.com/actualidad/ fundacin-elige-a-santiago-como-una-ciudad-resiliente-FBDL1219581).

PES 2020. 2015. 'Fundacion Rockefeller Selecciona a Santiago de los Caballeros como Ganador del Desafio 100 Ciudades Resilientes.' Plan Estrategico Santiago 2020. Retrieved 20 Noember 2018 (http://pesantiago.org/fundacion-rockefeller-seleccionasantiago-de-los-caballeros-como-ganador-del-desafio-100-ciudades-resilientes/).

Prior, T. and J. Hagmann, J. 2013. 'Measuring Resilience: Methodological and Political Challenges of a Trend Security Concept.' Journal of Risk Research 17 (3): 281-298, https://doi.org/10.1080/13669877.2013.808686.

Resilient Cities, undated. 100 Resilient Cities Project website. Retrieved 30 November 2018 (http://www.100resilientcities.org/).

Rockefeller Foundation, 2017. Cities Taking Action. How the 100 RC Network Is Building Urban Resilience. Retrieved 30 November 2018 (http://100reilientcities.org/ wp-content/uploads/2017/07/WEB_170720_Summit-report_100rc-1.pdf).

Rockefeller Foundation. undated a). 'About Us.' Retrieved 18 November 2018 (https://www.rockefellerfoundation.org/about-us/).

Rockefeller Foundation. undated b). '100 Resilient Cities.' Retrieved 18 November 2018 (https://www.rockefellerfoundation.org/our-work/initiatives/100-resilient-cities/).

Rogers, P. 2013. 'The Rigidity Trap in Global Resilience: Neoliberalisation Through Principles, Standards and Benchmarks.' Globalizations 10 (3): 383-395, https://doi.org/10.1080/14747731.2013.787834.

Rogers, P. 2017. 'The Etymology and Genealogy of a Contested Concept.' Pp. 13-25 in The Routledge Handbook of International Resilience, edited by D. Chandler and J. Coaffee. New York: Routledge.

Santiago Metropolitan Region (SMR). 2017. Santiago Humano \& Resiliente. Estrategia de Resiliencia. Santiago: SMR.

Schmidt, J. 2013. 'The Empirical Falsity of the Human Subject: New Materialism, Climate Change and the Shared Critique of Artifice.' Resilience: International Policies, Practices and Discourses 1 (3): 174-192, https://doi.org/10.1080/21693293.2013.837241.

Schmidt, J. 2015. 'Intuitively Neoliberal? Towards a Critical Understanding of Resilience Governance.' European Journal of International Relations 21 (2): 402-426, https://doi.org/10.1177/1354066114537533.

Scholz, R., Y. Blumer and F. Brand. 2012. 'Risk, Vulnerability, Robustness, and Resilience from Decision-Theoretic Perspective.' Journal of Risk Research 15 (3): 313-330, https://doi.org/10.1080/13669877.2011.634522. 
Singer, N. 2012. 'Mission Control, Built for Cities: I.B.M. Takes "Smarter Cities" Concept to Rio de Janeiro.' New York Times Online, 3 March 2012. Retrieved 30 November 2018 (https://www.nytimes.com/2012/03/04/business/ibm-takes-smarter-cities-conceptto-rio-de-janeiro.html).

Springer, S., K. Birch and J. McLeavy (eds). 2016. The Handbook of Neoliberalism. New York: Routledge, https://doi.org/10.4324/9781315730660.

UN-Habitat. 2007. Global Report on Human Settlements. Enhancing Urban Safety and Security. London: Earthscan.

United Nations Office for Disaster Risk Reduction. 2005. Marco de Accion de Hyogo para 2005-2015. Aumento de la resiliencia de las naciones y las comunidades ante los desastres. Hyogo: UNISDR.

United Nations Office for Disaster Risk Reduction. 2015. Sendai Framework for Disaster Risk Reduction 2015-2030. Sendai: UNISDR.

Uribe, B. 2014. 'Arquitectos Chilenos en Harvard logran poner a Santiago entre 100 ciudades resilientes.' Plataforma Arquitectura, 6 December. Retrieved 30 November 2018 (https://www.plataformaarquitectura.cl/cl/758653/arquitectos-chilenos-en-harvardlogran-poner-a-santiago-entre-100-ciudades-resilientes).

Vale, L. J. 2014. 'The Politics of Resilient Cities. Whose Resilience and Whose City?' Building Research \& Information 42 (2): 191-201, https://doi.org/10.1080/09613218.2014.850602.

Vale, L. J. and T. J. Campanella. 2005. The Resilient City: How Modern Cities Recover from Disaster. Oxford: Oxford University Press.

Walker, B. and D. Salt. 2006. Resilience Thinking: Sustaining Ecosystems and People in a Changing World. London: Island Press.

Walker, J. and M. Cooper. 2011. 'Genealogies of Resilience: From Systems Ecology to the Political Economy of Crisis Adaptation.' Security Dialogue 42 (2): 143-160, https://doi.org/10.1177/0967010611399616.

Zebrowski, C. 2013. 'The Nature of Resilience.' Resilience: International Policies, Practices and Discourses 1 (3): 159-173, https://doi.org/10.1080/21693293.2013.804672.

\section{Interviews}

Castillo, G., Advisor to the Ministry of Defence of Chile and to SeCRO. Interview, 14 November 2016, Ministry of Defence, Santiago, Chile.

Castro, C.P., Associate Professor, University of Chile. Interview, 18 November 2016, Faculty of Architecture and Urbanism, University of Chile, Santiago, Chile.

CIGIDEN researcher. Interview, 28 November 2016, PUC Campus San Joaquin, Santiago, Chile.

Fernandez, M., Senior Coordinator of City Resilience Profiling Programme. Interview, 10 October 2016, Avenida Diagonal, Barcelona, Spain.

Johnson, A., Resilience and Recovery Manager, City and County of San Francisco. Interview, 23 September 2015, Hotel Congressi, Rome, Italy.

NGO representative. Interview, 28 November 2016, San Diego, Santiago, Chile.

ONEMI official. Interview, 28 November 2016, Pontifica Universidad Catolica Campus San Joaquin, Santiago, Chile.

Ottelini, P., former San Francisco Chief Resilience Officer, City and County of San Francisco. Interview, 9 June 2016, City Hall of San Francisco, CA, USA.

Parra, A., UN Development Program for Latin America. Public lecture, 18 November 2016, PUC Campus Alameda, Centro de Extension, Santiago, Chile. 
PUC university professor. Interview, 28 November 2016, Pontifica Universidad Catolica Campus San Joaquin, Santiago, Chile.

Rivera, F., CIGIDEN researcher. Interview, 25 November 2016, Providencia, Santiago, Chile.

Robertson, C., Executive Director of 100 Resilient Cities Santiago. Interview, 23 November 2016, Santiago Metropolitan Region Government-Intendencia, Santiago, Chile.

Santiago commune official. Interview, 16 November 2016, Civil Protection Department, Comuna de Santiago, Plaza de Armas, Santiago, Chile.

Sarmiento, J.P., Florida International University. Interview, 18 November 2016, Faculty of Architecture and Urbanism, University of Chile, Santiago, Chile.

Simbieda, W.J., Professor of City and Regional Planning, California Polytechnic State University. Interview, 29 November 2016, Providencia, Santiago de Chile. 